\title{
Preservation treatment of fresh raspberries by e-beam irradiation
}

\author{
M.I. Elias ${ }^{\mathrm{a}, \mathrm{b}}$, J. Madureira ${ }^{\mathrm{a}, \mathrm{c}, \mathrm{d}}$, P.M.P. Santos ${ }^{\mathrm{a}}$, M.M. Carolino ${ }^{\mathrm{b}}$, F.M.A. Margaça ${ }^{\mathrm{a}}$, S. Cabo Verde ${ }^{\mathrm{a}, *}$ \\ ${ }^{a}$ Centro de Ciências e Tecnologias Nucleares (C C TN), Instituto Superior Técnico, Universidade de Lisboa, E.N. 10 ao km 139.7, 2695-066 Bobadela LRS, Portugal \\ ${ }^{\mathrm{b}}$ Centre for Ecology, Evolution and Environmental Changes (cE3c), Faculdade de Ciências, Universidade de Lisboa, Campo Grande, $1749-016$ Lisboa, Portugal

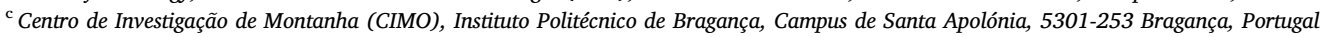 \\ ${ }^{\mathrm{d}}$ Grupo de Investigación en Polifenoles (GIP-USAL), Facultad de Farmacia, Universidad de Salamanca, Campus Miguel de Unamuno s/n, 37007 Salamanca, Spain
}

\section{A R T I C L E I N F O}

\section{Keywords:}

Raspberries

Microbial inactivation

Electron-beam treatment

Phenolic content

Antioxidant activity

Cytotoxicity

\begin{abstract}
A B S T R A C T
E-beam irradiation was studied as a post-harvest treatment for red raspberries (Rubus idaeus L.). Microbial inactivation (natural microbiota and potential pathogenic bacteria) and bioactive properties (phenolic content, vitamin $\mathrm{C}$ content and antioxidant activity and cytotoxicity) of these fruits were evaluated before and after irradiation and during storage of 14 days at $4{ }^{\circ} \mathrm{C}$. A reduction of $2 \log \mathrm{CFU} / \mathrm{g}$ of mesophilic bacteria and $3 \mathrm{log}$ $\mathrm{CFU} / \mathrm{g}$ on filamentous fungi, and no detection of foodborne inoculated pathogens ( $3 \mathrm{log} \mathrm{CFU} / \mathrm{g}$ ) was achieved with an e-beam treatment at $3 \mathrm{kGy}$ and during 7 days of refrigerated storage. Regarding bioactive properties, the results suggested that irradiation could preserve the phenolic content and antioxidant activity of raspberries through 7 days of cold storage, even though a decrease of $80 \%$ on ascorbic acid concentration was observed. Furthermore, no in vitro inhibitory effect on human cells lines was observed for the extracts from e-beam-treated raspberries. The overall results suggested that use of e-beam irradiation as post-harvest treatment of raspberries as an emergent, clean and environmental friendly process to extend the shelf-life of this fruit with safety and preservation of bioactivity.

Industrial relevance: Red raspberries are known to demonstrate high bioactivity that could be beneficial to human health, but are highly perishable and often associated with foodborne outbreaks, which makes its safety and commercialization a challenge. The use of a terminal control such as irradiation might reduce the burden of disease transmission and extend the quality of fresh red raspberries. The present research indicated that e-beam irradiation can be used as post-harvest treatment of raspberries, guarantying its safety and quality with the addvalue of shelf-life extension.
\end{abstract}

\section{Introduction}

Red raspberries (Rubus idaeus L.), a small fruit known as the "golden fruit", are becoming highly appreciated in the world and consumed as fresh and/or processed to juice, jams, confitures and other products or as ingredients for different foods (Teng et al., 2017). In Portugal, the production of high quality red raspberries has been considerably increased in the last years, becoming the second most exported fruit in the country (da Câmara Correia, 2016).

These fruits are known for their antitumoral, antibacterial, anti-inflammatory and antioxidant activities (Bowen-Forbes et al., 2010; de Souza et al., 2014; Sariburun et al., 2010) due to their content in phenolic compounds such as anthocyanins, ellagitannins, a wide variety of quercetin and kaempferol-based flavonol conjugates, phenolic acids and vitamin C (Bobinait et al., 2012; Bowen-Forbes et al., 2010; Diaconeasa et al., 2014; Kula et al., 2016; Mullen et al., 2002; Sariburun et al., 2010), among other beneficial nutrients including essential minerals, dietary fibre, potassium and fatty acids.

The contamination of the food supply with pathogens and their persistence, growth, multiplication and/or toxin production has emerged as an important public health concern (Paiva De Sousa, 2008), that also causes industrial economic losses. Fresh fruits and vegetables were considered the number one vehicle of foodborne illnesses, being associated to approximately 200 outbreaks, reported in United States and Europe during 2004-2012 (Callejón et al., 2015). Based on outbreak investigations, the pathogens associated with fruits and vegetables include pathogenic strains of Shiga toxin-producing Escherichia coli (STEC), Salmonella, Listeria monocytogenes and norovirus (Johnson, 2019). These three bacterial pathogens were involved in multistate fresh produce outbreaks from 2010 to 2017 in the United Sates (Carstens et al., 2019). Concerning berries, the majority of outbreaks associated to them have been caused by viruses, namely norovirus and

\footnotetext{
* Corresponding author.

E-mail address: sandracv@ctn.tecnico.ulisboa.pt (S. Cabo Verde).
} 
hepatitis A, although a Shigella sonnei outbreak has also been linked to these fruits (Tavoschi et al., 2015). Berries contamination and crosscontamination can be via equipment, water (irrigation and washing) and particularly via food handlers that have been identified as the main risk factors (EFSA BIOHAZ Panel - EFSA Panel on Biological Hazards, 2014). Raspberries are highly sensitive to the loss of water and susceptible to spoilage, which shortens their period of commercialization. Consequently, extending its shelf-life to improve distribution options, and to increase availability outside of peak production periods is challenging the research on post-harvest preservation technologies (Huynh et al., 2019). Currently, the berry industry rely mainly on cold chain management $\left(0-2{ }^{\circ} \mathrm{C}\right)$ and high humidity (90-98\%) for maintaining quality (Huynh et al., 2019). Moreover, raspberry is a fruit with an increasing consumption, impelling the berry fruit industry to improve food safety.

There are several methods to reduce and/or eliminate the microbial contamination on whole and fresh-cut produce (Parish et al., 2003). The addition of sanitizers or disinfectants to water washes is one of the most commonly applied strategy to inactivate pathogens on berries. For example, chlorine washes of berries generally yield 1- to 2-log unit reductions in bacteria and viruses (Lukasik et al., 2003; Wei et al., 2007). Despite of the general use of sodium hypochlorite and hydrogen peroxide as sanitizers (Artés et al., 2009), it is well documented that these compounds can cause irritations in the skin and the respiratory tract and could have an carcinogenic effect. Alternatively, electrolyzed water has been used as a disinfectant in fresh-cut industry (IssaZacharia et al., 2010; Lee et al., 2014).

Ionizing radiation is considered an effective technology for microbial inactivation and shelf-life extension. In previous studies, Cabo Verde et al. (2013) showed that gamma radiation at $1.5 \mathrm{kGy}$ could reduce the microbial load on raspberry by 1 log unit without changes in the sensorial quality of the fruit. Regarding the inactivation of enteric virus by gamma radiation in berry fruits, Pimenta et al. (2019) reported a $2 \log \mathrm{PFU} / \mathrm{g}$ (Plaque Forming Units per gram) reduction on murine norovirus type 1 (MuNoV) and human adenovirus type 5 (HAdV) after treatment at $4 \mathrm{kGy}$. Moreover, the use of gamma radiation at 1 and $2 \mathrm{kGy}$, associated with cold storage, extended the post-harvest life of fresh raspberries by 8 days (Tezotto-Uliana et al., 2013). In addition, the use of electron-beam irradiation as an environmental friendly and time effective alternative for decontamination, disinfection and disinfestation of fresh fruits has been proposed (Lung et al., 2015; Madureira et al., 2019).

The aim of this work was to evaluate the potential use of the ecofriendly e-beam irradiation as a post-harvest treatment for raspberries through the evaluation of microbial inactivation (natural microbiota and potential pathogenic bacteria) and bioactive activity (phenolic content, vitamin $\mathrm{C}$ content and antioxidant activity and cytotoxicity). To our knowledge, there is no study concerning the use of e-beam irradiation as a post-harvest treatment for shelf-life extension of fresh raspberries. Thus, this work can contribute to better understand the potential use of this technology as a treatment process to further increase the safety, quality and economic value of these fruits. One of the major advantage using radiation technologies is that they require a minimal handling of the food item. Consequently, decontamination is achieved without inducing any mechanical damage and the time needed for the product to reach consumers is substantially reduced (Guimarães et al., 2013).

\section{Materials and methods}

\subsection{Sampling}

Red raspberries (Rubus idaeus L., cv. Amira) of uniform shape size at commercial maturity stage were purchased from a local supermarket in Lisbon, Portugal, and immediately kept at $4 \pm 1{ }^{\circ} \mathrm{C}$ until analysis. The fruits had no visible mechanical damage or pathogen damage. In a study developed by da Câmara Correia (2016), four cultivars were compared and the cv. Amira showed high levels of total phenolics, total hydrolyzable tannins, total flavonoids and total anthocyanins, and chosen for biological assays and for a study of nutritional intervention in humans.

\subsection{Irradiation experiments}

Irradiation experiments were carried out in a linear electron-beam accelerator (LINAC, adapted from GE Saturne 41) with an energy of $10 \mathrm{MeV}$ located at the ionizing radiation facility IRIS from Centro de Ciências e Tecnologias Nucleares (C2TN) of Instituto Superior Técnico, Universidade de Lisboa.

Fresh raspberries were irradiated in plastic boxes (150 g; one box per dose) at room temperature at doses from 0.5 to $3 \mathrm{kGy}$ at an average

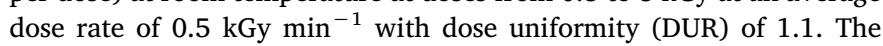
absorbed dose was estimated using calibrated radiochromic dosimeters FWT-60 (Far West Technology, Inc. Goleta, USA) (Miller, 1983). Three independent irradiation batches were performed per each assay. Nonirradiated samples $(0 \mathrm{kGy})$ were used as control and followed all the experiments.

\subsection{Microbial inactivation studies}

\subsubsection{Natural microbiota}

Non-irradiated and irradiated raspberries $(25 \mathrm{~g})$ were placed in sterile stomacher bags containing $100 \mathrm{~mL}$ of $0.1 \%$ Tween 80 physiological solution. Samples ( $n=3 /$ dose) were homogenized using a stomacher (Stomacher 3500; Seaward, UK) for $15 \mathrm{~min}$. Serial decimal dilutions were prepared for inoculation in triplicate on Tryptic Soy Agar plates (TSA) for mesophilic microbial counts and Malt Extract Agar (MEA) plates for filamentous fungi counts. Samples were incubated at $30{ }^{\circ} \mathrm{C}$ for TSA plates and $28^{\circ} \mathrm{C}$ for MEA plates and colony numbers were counted for 7 days. The results were expressed as log colony-forming units per gram of fresh fruit $(\log \mathrm{CFU} / \mathrm{g})$.

\subsubsection{Artificial inoculation with potential foodborne pathogens}

Artificial contamination assays were carried out using three different bacterial strains in separated sets, namely Salmonella enterica serotype Typhimurium ATCC 14028, Escherichia coli ATCC 8739 and Listeria monocytogenes ATCC 19111. To inoculate the raspberries (previously disinfected with $70 \%$ ethanol until completely evaporated under a laminar flow cabinet), a droplet of inoculum was deposited on the skin of the fruits ( $25 \mathrm{~g}$ ) to obtain approximately $10^{3} \mathrm{CFU} / \mathrm{g}$ of each bacterium. The fruits were dried in a laminar flow cabinet to allow the attachment of the microorganisms. Bacterial counts of spiked raspberries samples were estimated as described by Madureira et al. (2019). The detection limit of the method was $1 \mathrm{CFU} / \mathrm{g}$. The microbial counts were recorded and expressed as the $\log \mathrm{CFU} / \mathrm{g}$. $\mathrm{D}_{10}$ is defined as the dose (kGy) required to inactivate $90 \%$ of a microbial population, or the dose of irradiation needed to produce a 10 -fold (1 log) reduction in the population. $\mathrm{D}_{10}$ values were estimated by the reciprocal of the slope of the log-linear microbial survival curves.

\subsection{Phenolic compounds extraction}

Raspberries (18 g) were manually mashed and lyophilized (Heto CD8, Allerod, Denmark) for $72 \mathrm{~h}$ and stored until used. The raspberry extracts were prepared by a solid-liquid extraction as previously described (Pinela et al., 2016), using a mixture of ethanol:water (80:20, $v$ / $\mathrm{v} ; 30 \mathrm{~mL}$ ) as solvent, for $1 \mathrm{~h}$ at room temperature.

\subsubsection{Ascorbic acid content}

Ascorbic acid content was determined by High Performance Liquid Chromatography (HPLC) (Prominence CBM 20-A, Shimadzu, Japan) with UV-DAD detector. The lyophilized extracts $(\sim 10 \mathrm{mg})$ were 
dissolved in metaphosphoric acid 4.5\% (1 mL). All samples were filtered through $0.45-\mu \mathrm{m}$ nylon filters before analysis. The HPLC column was a Kinetex C18 XB-C18 ( $5 \mu \mathrm{m}, 250 \mathrm{~mm}, 4.0 \mathrm{~mm})$ and the detection was made at $245 \mathrm{~nm}$. The mobile phase used was $1.8 \mathrm{mM} \mathrm{H}_{2} \mathrm{SO}_{4}$ $(\mathrm{pH}=2.6)$ with a flow rate of $0.9 \mathrm{~mL} \mathrm{~min}^{-1}$. The column temperature was maintained at $35{ }^{\circ} \mathrm{C}$ and the injection volume was $10 \mu \mathrm{L}$. The assay was made in triplicate. For quantification purposes, a calibration plot was performed under the experimental conditions used. Values were expressed as mg per $100 \mathrm{~g}$ of raspberries dry weight (dw).

\subsubsection{Total phenolic content}

The total phenolic content was determined based on FolinCiocalteau method (Singleton et al., 1998), in extracts concentrated at $5 \mathrm{mg} / \mathrm{mL}$. The standard curve was calculated using gallic acid (Sigma, St. Louis, US) and the results were expressed as mg of gallic acid equivalents (GAE) per $100 \mathrm{~g}$ of raspberries dry weight (dw) (Guerreiro et al., 2016). The assay was carried out in triplicate.

\subsubsection{Antioxidant activity}

The antioxidant activity was evaluated by two assays based on different mechanisms of action: DPPH radical scavenging activity described by Brand-Williams et al. (1995) with some modifications (Madureira et al., 2019) using EZ Read 2000 Microplate Reader (Biochrom, Cambridge, UK) and Ferric Reducing Antioxidant Power (FRAP) described by Benzie and Strain (1996) using a spectrophotometer (Shimadzu UV 1800, Kyoto, Japan). For FRAP assay, the results were expressed as mmol of ferrous sulfate equivalent (FSE) per $100 \mathrm{~g}$ raspberries dry weight $(\mathrm{dw})$. For DPPH method, L-ascorbic acid (E-Merck, Darmstadt, Germany) was used as standard compound for the calibration. The antioxidant activity measured by DPPH scavenging activity was expressed as EC50 values (mean \pm standard error), which means that higher values correspond to lower antioxidant potential (EC50: extract concentration corresponding to $50 \%$ of antioxidant activity). Both assays were made in triplicate.

\subsubsection{Cytotoxicity assay - WST-1 proliferation test}

Human lung carcinoma epithelial cells (A549, ATCC ${ }^{\circledR}$ CCL-185TM) and human embryonic kidney epithelial cells (293 T, ATCC ${ }^{\circledR}$ CRL$3616^{\mathrm{TM}}$ ) were used. Cell viability after exposition to raspberries extracts (at the concentrations of 4,40 and $400 \mu \mathrm{g} / \mathrm{mL}$ ) was measured using the WST-1 cell proliferation assay based on quantification of mitochondrial activity as an indicator of cytotoxicity based on the protocol described by Madureira et al., 2019. Two independent assays each with three raspberries extracts replicates were performed.

\subsection{Storage study}

In order to evaluate a potential shelf-life extension of raspberries with e-beam treatment, the previously described assays were performed at different refrigerated $\left(4{ }^{\circ} \mathrm{C}\right)$ storage periods. The microbial inactivation assessments, the vitamin $\mathrm{C}$ and phenolic contents, the antioxidant activity and the cytotoxicity of the extracts were carried out after irradiation either immediately (T0; no storage) or followed by different storage periods: 3 days (T3; regular fruit shelf-life), 7 days (T7) and 14 days (T14).

\subsection{Data analysis}

Origin software version 7.5 (OriginLab Corporation, Northampton, USA) was used for data analysis. Confidence intervals for means values were estimated considering a significance level of $p<0.05$ and the number of replicates for each assay. The results were analysed using one-way analysis of variance (ANOVA) followed by Tukey's HSD test with $\alpha=0.05$.
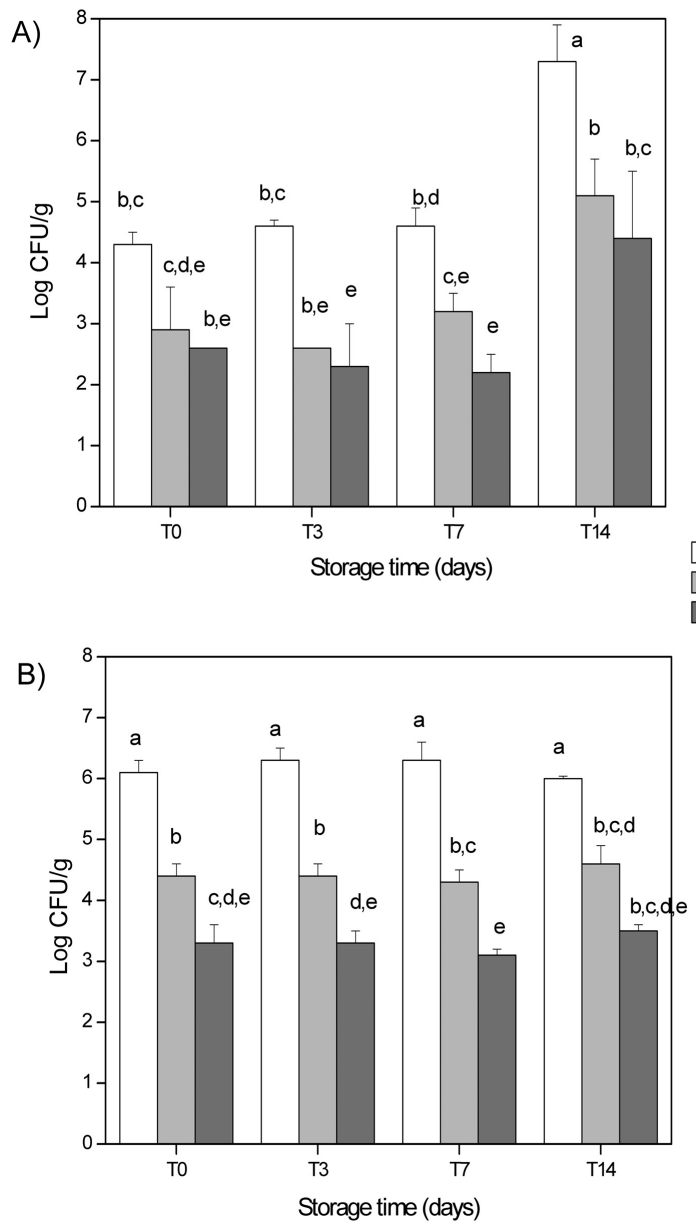

Fig. 1. Natural microbiota counts for non-irradiated (white) and irradiated raspberries (light grey $2 \mathrm{kGy}$; dark grey $3 \mathrm{kGy}$ ) immediately after irradiation (T0) and after 3 (T3), 7 (T7) and 14 (T14) days of refrigerated storage: A) aerobic mesophilic bacterial population, and B) filamentous fungi population. Standard deviation bars correspond to $95 \%$ confidence intervals about mean values $(n=18 ; \alpha=0.05)$.

\section{Results and discussion}

As mentioned above, this is the first study applying e-beam radiation to treat and extend the shelf-life of fresh raspberries, being the obtained results important to understand the possible use of this technology in the industry as a post-harvest process of fruits. The applied dose range was selected based on WHO guidelines for fresh fruits shelflife extension (World Health Organisation \& Food and Agriculture Organization of the United Nations, 2000).

\subsection{Microbial inactivation}

The aerobic mesophilic bacteria and filamentous fungi populations of fresh raspberries were assessed before and after e-beam treatment, immediately after irradiation (T0) and after several periods, namely 3 days (T3), 7 days (T7) and 14 days (T14) of refrigerated storage, in order to evaluate the microbial inactivation and its trend with the treatment and storage. The fresh raspberries indicated an aerobic bacterial mesophilic population of $4.3 \pm 0.1 \mathrm{log} \mathrm{CFU} / \mathrm{g}$ and a filamentous fungi population of $6.1 \pm 0.1 \mathrm{log} \mathrm{CFU} / \mathrm{g}$ (Fig. 1). Previously, an average bioburden between 4 and $6 \log \mathrm{CFU} / \mathrm{g}$ was reported for fresh raspberries (Baugher \& Jaykus, 2016; Cabo Verde et al., 2013; Piechowiak et al., 2019), that supports the obtained results. Nevertheless, the production practices, growth conditions in combination with harvesting and processing, can affect the microbiological quality 
of berries at the time of consumption (Oliveira et al., 2019).

With e-beam treatment at $3 \mathrm{kGy}$ (T0) the mesophilic bacterial population of raspberries decreased $(p<0.05) 2 \log \mathrm{CFU} / \mathrm{g}$ and the filamentous fungi reduced $(\mathrm{p}<0.05) 3 \mathrm{log} \mathrm{CFU} / \mathrm{g}$ comparatively to non-treated samples (Fig. 1). The e-beam treatment allowed to comply with the Portuguese recommended criteria for fresh fruits and vegetables (bacterial counts at $30{ }^{\circ} \mathrm{C}<4 \log \mathrm{CFU} / \mathrm{g}$; filamentous fungi $<5$ $\log \mathrm{CFU} / \mathrm{g}$; Santos et al., 2005). In fact, there is no regular monitoring of berries and the current European Union legal framework does not include microbiological criteria applicable for these fruits at the primary production stage (Oliveira et al., 2019).

The bacterial counts of non-treated fruits remained constant $(p>0.05)$ during 7 days of refrigerated storage, but an increase $(p<0.05)$ of $3 \log \mathrm{CFU} / \mathrm{g}$ was observed at 14 day of storage. Nevertheless, the fungal population remained $(\mathrm{p}>0.05)$ at approximately $6 \log \mathrm{CFU} / \mathrm{g}$ during the 14 days of refrigerated storage (Fig. 1). A statistically significant growth of bacteria up to $7 \log \mathrm{CFU} / \mathrm{g}$ was cited after $24 \mathrm{~h}$ of storage of fresh raspberries at room temperature (Piechowiak et al., 2019). For irradiated raspberries the same trend of control samples was observed, the bacterial counts increased $(\mathrm{p}<0.05) 2 \log \mathrm{CFU} / \mathrm{g}$ only after 14 days of storage, and the filamentous fungi counts were maintained $(\mathrm{p}>0.05)$ for 14 days of storage (Fig. 1). After the 14 days of refrigerated storage, the bacterial counts of $3 \mathrm{kGy}$ treated raspberries were similar $(p>0.05)$ to the initial counts of non-treated samples (T0), but for fungi the concentration of treated raspberries was always lower $(p<0.05)$ than control (0 kGy). It should be highlighted that the e-beam treatments at $2 \mathrm{kGy}$ and $3 \mathrm{kGy}$ complied with the recommended limits for microbial loads (Santos et al., 2005) through 7 days storage, that were not meet by the non-treated raspberries at any period of analysis.

Previous studies reported one log reduction of microbial load of fresh raspberries after gamma radiation treatment at $1.5 \mathrm{kGy}$ and during 14 days of refrigerated (Cabo Verde et al., 2013). A similar inactivation (approximately $1 \log \mathrm{CFU} / \mathrm{g}$ ) on aerobic mesophilic bacteria and fungi was obtained for fresh raspberries stored at room temperature during $48 \mathrm{~h}$ and treated by ozonation with a dose of 8-10 ppm for $30 \mathrm{~min}$ every $12 \mathrm{~h}$ (Piechowiak et al., 2019).

Regarding the inactivation of foodborne bacteria, which were artificially inoculated on fruits, the results are presented in Table 1. Different ranges of absorbed doses were used for each microorganism in order to have surviving fractions for the $\mathrm{D}_{10}$ values estimation. Salmonella Typhimurium on raspberries presented a linear $\left(\mathrm{R}^{2}=0.99\right)$ inactivation kinetics by e-beam irradiation and $a D_{10}$ value of $0.73 \pm 0.05 \mathrm{kGy}$. This bacteria was not detected on fruits treated at $3 \mathrm{kGy}$ for the 14 days of storage (Table 1). The population of $S$. Typhimurium on non-treated raspberries significantly $(p<0.05)$ decreased $(<1 \log \mathrm{CFU} / \mathrm{g}$ ) after 3 days of storage, thereafter maintained ( $p>0.05$ ) its counts until the 14 days (Table 1 ). On irradiated raspberries, the refrigerated storage indicated a reduction of $S$. Typhimurium counts along the 14 days, suggesting a synergistic effect between storage and irradiation on the inactivation of this bacteria. Salmonella is documented to be very sensitive to berry phenolics (Heinonen, 2007), which could be exposed due to raspberries tissue softening during storage (Cabo Verde et al., 2013; Huynh et al., 2019). This synergistic effect between cold storage and gamma radiation on the delay of the decay of raspberries was mentioned before, pointing out to an extension of the post-harvest life for fruit irradiated at 1.0 and 2.0 kGy by 8 days (Tezotto-Uliana et al., 2013).

E. coli on raspberries also followed a linear inactivation $\left(\mathrm{R}^{2}=0.99\right)$ by e-beam irradiation with an estimated $\mathrm{D}_{10}$ value of $0.72 \pm 0.01 \mathrm{kGy}$. Similarly to $S$. Thyphimurium, on raspberries irradiated at $3 \mathrm{kGy}$ it was not detected the presence of $E$. coli for any period of analysis. Once again, the extended refrigerated storage induced a decrease on bacterial counts $(0 \mathrm{kGy} \mathrm{T0}, \mathrm{T} 3$ and T7, T14; $\mathrm{p}<0.05)$, more pronounced for irradiated fruits at $1.5 \mathrm{kGy}$ where $E$. coli was not detected on stored samples (Table 1). According to the literature, berry compounds (e.g.

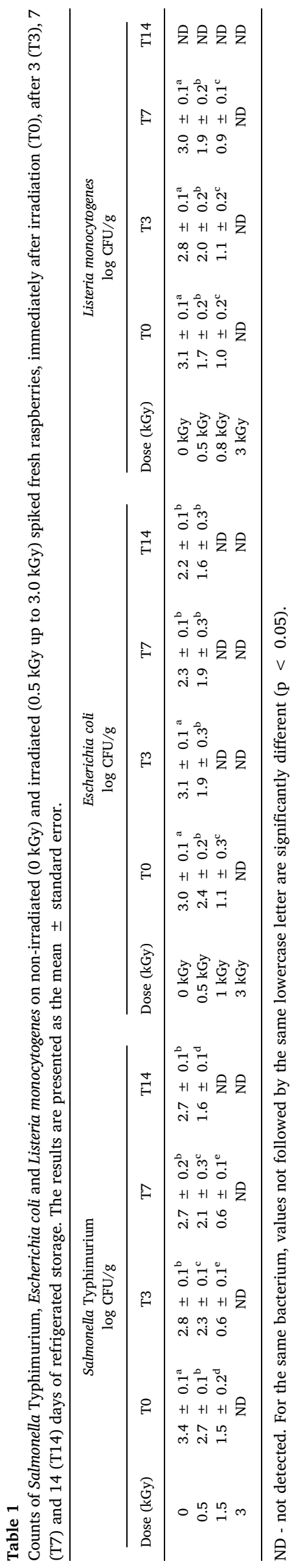


complex phenolic polymers such as polymeric tannins) are able to inhibit the growth of this bacteria (Heinonen, 2007). Again, the loss of firmness of raspberries during storage may allow the penetration of surface bacterial contamination to be are exposed to the antimicrobial compounds of this fruit.

Among the foodborne bacteria studied, Listeria monocytogenes, was found to be the most radiosensitive to e-beam on raspberries, following a linear $\left(R^{2}=0.99\right)$ inactivation kinetics characterized by a $D_{10}$ value of $0.41 \pm 0.03 \mathrm{kGy}$. This microorganism was not detected on raspberries irradiated at $3 \mathrm{kGy}$ (like $S$. Typhimurium and $E$. coli), as well as on all the samples stored at 14 days (Table 1). Nonetheless, the counts reduction was not observed along the 7 days of storage, as it was for $E$. coli and $S$. Typhimurium. As previously reported, L. monocytogenes possesses the ability to survive in food matrices at refrigerator temperatures, reaching a steady state that lasts at least up to 8 days (maximum days tested) of storage (Ziegler et al., 2019). Moreover, other studies indicated that Listeria strains were not affected by berry compounds, with the exception of cranberry (Puupponen-Pimia et al., 2005).

The previous results highlight the efficiency of e-beam as a disinfection process. Based on the estimated $D_{10}$ values, the treatment at $3 \mathrm{kGy}$ is expected to reduce $S$. Typhimurium and E.coli by $4 \log \mathrm{CFU} / \mathrm{g}$, and L. monocytogenes by $8 \log \mathrm{CFU} / \mathrm{g}$ on post-harvested raspberries.

Other preservation technologies have been studied to guarantee the microbial safety of raspberries. For example, the combined continuous and pressurized ozone treatment indicated to achieve reductions of 3.6 and $3.8 \mathrm{log} \mathrm{CFU} / \mathrm{g}$ for Salmonella enterica and E. coli O157:H7, respectively (K.L. Bialka \& Demirci, 2007). Previous studies indicated that pulsed UV-light treatment on raspberries can reduce $E$. coli O157:H7 by $3.9 \log \mathrm{CFU} / \mathrm{g}$ at $72 \mathrm{Jcm}^{-2}$, and Salmonella by $3.4 \mathrm{log} \mathrm{CFU} / \mathrm{g}$ at 59.4 $\mathrm{Jcm}^{-2}$ (K.L. Bialka \& Demirci, 2008). Other study, using UV-C presented that a treatment during $720 \mathrm{~s}$ with a total dose of $0.78 \mathrm{Jcm}^{-2}$ can yield a $1.5 \log \mathrm{CFU} / \mathrm{g}$ reduction of Listeria monocytogenes population on the surface of frozen red raspberries (Te Liao et al., 2017). The combined treatment of $1 \% \mathrm{H}_{2} \mathrm{O}_{2}$ with water-assisted pulsed light system indicated to reduce $S$. enterica on raspberries by $4 \log \mathrm{CFU} / \mathrm{g}$ (Huang et al., 2015). The preservation treatment of raspberries with gaseous chlorine dioxide presented reductions of $1.5 \mathrm{log} \mathrm{CFU} / \mathrm{g}$ for Salmonella enterica and $2.6 \mathrm{log} \mathrm{CFU} / \mathrm{g}$ for yeasts and molds, using $8 \mathrm{mg} /$ $\mathrm{L}$ of $\mathrm{ClO}_{2}$ during $120 \mathrm{~min}$ (Sy, Sy et al., 2005). Comparing the results obtained in the present study with the ones mentioned above, the ebeam treatment at $3 \mathrm{kGy}$ demonstrated similar or higher decontamination (2-3 log CFU/g reduction) and disinfection efficacy (at least 4 $\log \mathrm{CFU} / \mathrm{g}$ reduction), with the benefits of being a single treatment (non-combined) with no chemical/residues and no further manipulations (final treatment that can be performed in the regular packaging system), preventing cross-contamination, and a potential extension of shelf-life up to 7 days for raspberries.

\subsection{Phenolic content and antioxidant activity of raspberries extracts}

It is recognized that the phenolic compounds contribute to the nutritional and sensory quality of fruits and their antioxidant potential provide health benefits (Shahbaz et al., 2014). The obtained results of total phenolic content (TP) and antioxidant activity of raspberries before and after irradiation and during storage time are presented in Table 2 . The bioactivity assessment was only performed at $3 \mathrm{kGy}$ since it was the dose that comply with the microbiological criteria. The obtained TP value for non-irradiated fruits was $1092 \pm 3 \mathrm{mg} \mathrm{GAE} / 100 \mathrm{~g}$ dry weight and, with exception of non-stored irradiated sample (T0, $3 \mathrm{kGy}$ ), no significant trend was verified for the 14 days of storage at $4{ }^{\circ} \mathrm{C}$. The irradiation of raspberries at $3 \mathrm{kGy}$ seemed to increase significantly $(p<0.05)$ the phenolic content $(1405 \pm 75 \mathrm{mg} \mathrm{GAE} / 100 \mathrm{~g}$ dry weight) in comparison to control sample. This increase could be related to an improvement of extractability of phenolic compounds with irradiation (Pereira et al., 2015) possibly due to fruit structure
Table 2

Antioxidant activity (DPPH and FRAP assays) and Total Phenolic Content in extracts of non-irradiated and irradiated raspberries analysed immediately after e-beam irradiation and during 14 days of refrigerated storage. The results are presented as the mean \pm standard error.

\begin{tabular}{|c|c|c|c|c|}
\hline Storage time & Dose & $\begin{array}{l}\text { DDPH } \\
\text { scavenging } \\
\text { activity }\end{array}$ & FRAP & $\begin{array}{l}\text { Total Phenolic } \\
\text { Content }\end{array}$ \\
\hline (days) & (kGy) & $\left(\mathrm{EC}_{50} \mu \mathrm{g} / \mathrm{mL}\right)$ & $\begin{array}{l}\text { (mmol FES/ } \\
100 \mathrm{~g} \mathrm{dw} \text { ) }\end{array}$ & $\begin{array}{l}\text { (GAE mg/100 g } \\
d w)\end{array}$ \\
\hline \multirow[t]{2}{*}{0} & 0 & $2028 \pm 24^{\mathrm{a}}$ & $17.5 \pm 0.1^{\mathrm{b}}$ & $1092 \pm 3^{b}$ \\
\hline & 3 & $1964 \pm 39^{\mathrm{a}}$ & $13 \pm 1^{c}$ & $1405 \pm 75^{\mathrm{a}}$ \\
\hline \multirow[t]{2}{*}{3} & 0 & $1698 \pm 17^{\mathrm{b}}$ & $17.2 \pm 0.1^{\mathrm{b}}$ & $1054 \pm 13^{\mathrm{b}}$ \\
\hline & 3 & $1924 \pm 36^{\mathrm{a}}$ & $18.3 \pm 0.6^{\mathrm{a}, \mathrm{b}}$ & $1012 \pm 87^{\mathrm{b}}$ \\
\hline \multirow[t]{2}{*}{7} & 0 & $1706 \pm 38^{\mathrm{b}}$ & $17.8 \pm 0.5^{\mathrm{b}}$ & $1078 \pm 5^{\mathrm{b}}$ \\
\hline & 3 & $1651 \pm 24^{\mathrm{b}}$ & $18 \pm 1^{\mathrm{a}, \mathrm{b}}$ & $1099 \pm 70^{b}$ \\
\hline \multirow[t]{2}{*}{14} & 0 & $1201 \pm 12^{\mathrm{d}}$ & $21.3 \pm 0.1^{\mathrm{a}}$ & $1145 \pm 23^{\mathrm{a}, \mathrm{b}}$ \\
\hline & 3 & $1401 \pm 26^{c}$ & $20.3 \pm 0.2^{\mathrm{a}, \mathrm{b}}$ & $1067 \pm 59^{b}$ \\
\hline
\end{tabular}

Within the column, values not followed by the same lowercase letter are significantly different $(\mathrm{p}<0.05)$.

alterations, and/or to the radiolytic breakage of larger phenolic compounds (e.g. tannins) into smaller ones (P.R. Hussain et al., 2016). Despite of the literature scarcity on the effects of electron-beam radiation on raspberries, Guimarães et al. (2013) observed an increase on phenolic content of raspberries with gamma radiation at $2 \mathrm{kGy}$ and during storage, while Cabo Verde et al. (2013) observed an increase of phenolic content with gamma radiation doses up to $1.5 \mathrm{kGy}$ (T0) with decrease during the storage time. Other preservation technologies tested on raspberries indicated different effects on total phenolic content, namely no effect with chlorophyllin-based photosensitization treatment (Rasiukevičiūtè et al., 2015), or a positive impact (higher level of phenolics) by ozonation process (Piechowiak et al., 2019).

Concerning FRAP assay results, no variation was observed on the antioxidant activity with the refrigerated storage of the raspberries, except for those stored during 14 days (T14, $0 \mathrm{kGy}$ ) that presented significantly $(p<0.05)$ higher antioxidant activity. The e-beam treatment significantly $(\mathrm{p}<0.05)$ decreased the antioxidant activity by FRAP of non-stored fruits (T0, $3 \mathrm{kGy}$ ), but the storage tended to increase $(\mathrm{p}<0.05)$ the antioxidant potential of irradiated fruits that presented similar values $(p>0.05)$ to stored controls.

The antioxidant activity of raspberries measured by DPPH scavenging activity, indicated a significant increase $(p<0.05)$ with storage at $4{ }^{\circ} \mathrm{C}$, with higher values for raspberries stored during 14 days. The ebeam treatment pointed out to preserve the antioxidant activity by DPPH of non-stored raspberries (T0). Although it was detected an increase of TP on non-stored and irradiated raspberries, it was not reflected on an increase of antioxidant potential as expected. This fact suggests that new phenolic compounds can be formed upon e-beam treatment that do not necessarily exert their antioxidant activity by single electron transfer, which is the dominant reaction mechanism present in both FRAP and DPPH assays. The total antioxidant activity of raspberries should be considered as a combination of different phytochemicals that can act by additive or synergistic effects. In turn, the storage of e-beam treated fruits induced an increase $(p<0.05)$ of antioxidant activity by DPPH after 7 days, which not corresponded to an increase in TP value. This result could reflect an improvement by irradiation and storage on the extractability of non-phenolic antioxidant compounds.

For raspberries treated by gamma radiation, it was observed an increase of antioxidant activity by FRAP with a dose of $1.5 \mathrm{kGy}$ (T0) and a decrease after 14 days of refrigerated storage (Cabo Verde et al., 2013), but Guimarães et al. (2013) observed an increasing trend on antioxidant activity at a dose of $2 \mathrm{kGy}$ during 12 days refrigerated storage. Other post-harvest preservation technologies also indicated 


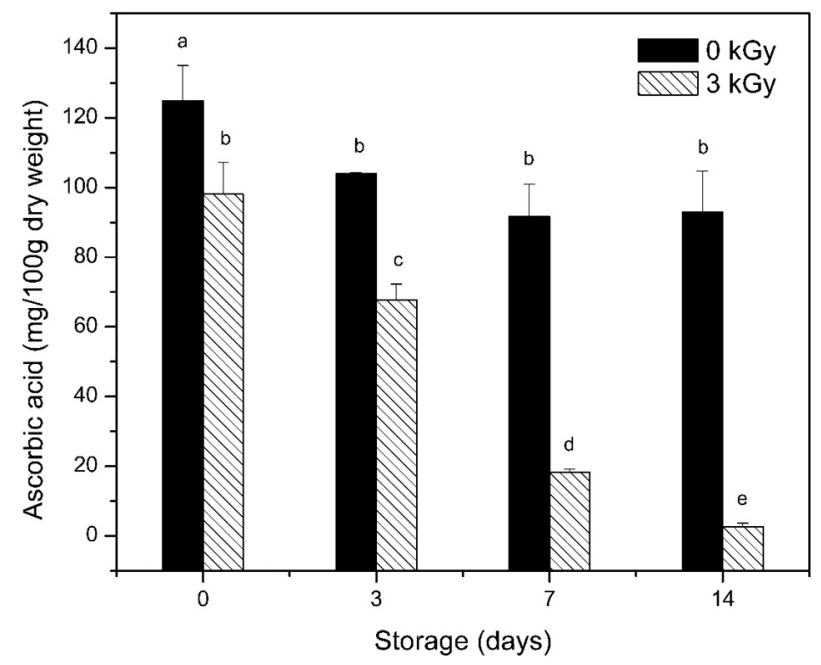

Fig. 2. Effect of electron-beam radiation on ascorbic acid content (mg/100 $\mathrm{g}$ of dry weight) of raspberries during the storage. Standard deviation bars correspond to $95 \%$ confidence intervals about mean values $(n=6 ; \alpha=0.05)$. Bars not followed by the same lowercase letter are significantly different $(p<0.05)$.

dissimilar effects on antioxidant activity of raspberries, for example, chlorophyllin-based photosensitization treatment had no significant change as measured by DPPH (Rasiukevičiūtè et al., 2015), and ozonation process caused an increase (by DPPH) after treatment and a decrease was detected at $48 \mathrm{~h}$ of storage (Piechowiak et al., 2019).

The overall results seemed to indicate that e-beam treatment could guarantee the preservation of phenolic content and antioxidant activity of raspberries during 7 days of cold storage.

\subsection{Ascorbic acid content}

Ascorbic acid is an important water-soluble and carbohydrate-like nutrient that is very sensitive to both chemical and enzymatic oxidation during food processing and storage, when compared to other nutrients. The amount of ascorbic acid in non-treated raspberries was $125 \pm 5 \mathrm{mg} / 100 \mathrm{~g}$ of dry weight (Fig. 2). Immediately after irradiation (T0), a significant decrease $(\mathrm{p}<0.05)$ in ascorbic acid content was caused by e-beam treatment. This depletion can easily be attributed to its significant capacity to scavenge radical species formed upon water radiolysis that occurs in the fruit medium, in particular the highly reactive hydroxyl radical. Ascorbic acid also manifests its antioxidant activity by a direct protection of other compounds from oxidative degradation (Wong \& Kitts, 2001). Both mechanisms result in a (reversible) oxidation of ascorbic acid to dehydroascorbic acid that can be further hydrolyzed and oxidized irreversibly into other products (Deutsch, 2000). During cold storage, ascorbic acid is prone to decrease by enzymatic oxidation. However, the effect on control samples was less pronounced than in treated ones, since after 3 days of storage the amount of ascorbic acid remained similar $(p>0.05)$. The antioxidant activity of ascorbic acid by any of the mechanisms referred to above is expected to last during storage for treated raspberries, and this behaviour can explain the significantly higher depletion observed.

The obtained results are in agreement with those reported by Tezotto-Uliana et al. (2013), which observed a decrease in ascorbic acid levels for non-irradiated and gamma irradiated raspberries during the storage with higher reduction for higher radiation doses. Similar decreasing tendencies of ascorbic acid was observed on raspberries treated by other non-thermal processes and during refrigerated storage (Piechowiak et al., 2019). The degradation of ascorbic acid present in raspberries did not result on a lower antioxidant activity, which could be justified by the oxidation of ascorbic acid to dehydroascorbic acid (a biologically active compound) as observed by P.R. Hussain et al. (2012) for strawberries. It was estimated that ascorbic acid contribute around $20 \%$ to the total antioxidant capacity of raspberries (Beekwilder et al., 2005). Dehydroascorbic acid has a recognized physiological role since it can be used by metabolically competent cells, where it is reduced back to ascorbic acid, being also widely accepted that dietary ascorbic acid and dehydroascorbic acid have equivalent bioavailability in humans (Wilson, 2002). In this way, the use of irradiation will not result in a severe loss of nutritional value on raspberries.

\subsection{Cytotoxicity assessment of raspberries extracts}

Studies have indicated that in raspberry extracts, some individual polyphenols (e.g. anthocyanins, ellagitannins, and ellagic acid) or together with other compounds (e.g. ascorbic acid, carotenoids) with synergetic effects, have anti-proliferative activity against cancer cells in vitro (McDougall et al., 2008). In view of all these, the effects of e-beam treatment on the cytotoxicity of raspberries extracts were evaluated by the WST-1 cell viability assay using two human cells lines, human embryonic kidney 293 (293 T, non-tumor) cell line; and A549 a lung tumor cell line, to assess potential antitumor activity. The obtained results of $\%$ of cell viability from the two cell lines exposed to three concentrations of extracts from raspberries non-irradiated, irradiated at $3 \mathrm{kGy}$, non-stored and stored are presented in Fig. 3. For nontumorigenic cell line (293 T), the higher extract concentration $(400 \mu \mathrm{g} /$ $\mathrm{mL})$ prompted a significant $(p<0.05)$ inhibitory effect on cell viability, independently of fruit treatment and storage time. The extracts of non-treated and treated fruits at 4 and $40 \mu \mathrm{g} / \mathrm{mL}$ have no significant $(p>0.05)$ effect on cell proliferation, except for the 14 days of storage where all fruits extracts have anti-proliferative activity against $293 \mathrm{~T}$
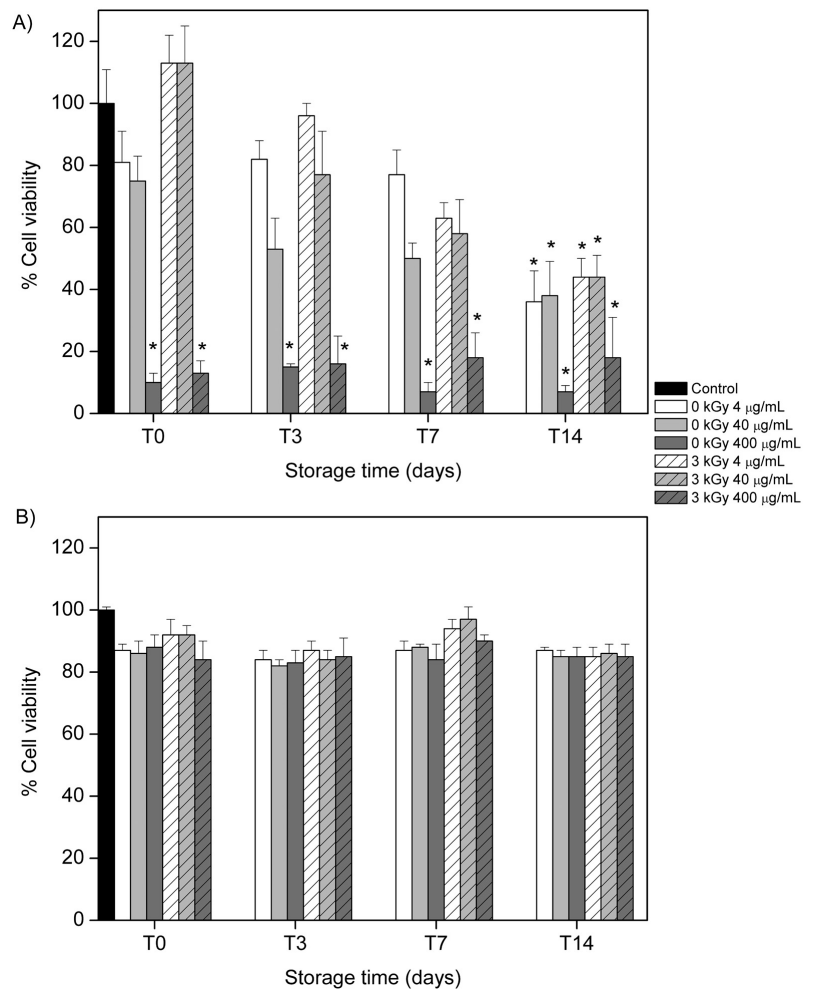

Fig. 3. Cellular viability of A) $293 \mathrm{~T}$ and B) A549 cell lines in the presence of different concentrations ( $4 \mu \mathrm{g} / \mathrm{mL}, 40 \mu \mathrm{g} / \mathrm{mL}$ and $400 \mu \mathrm{g} / \mathrm{mL}$ ) of raspberries extracts from non-irradiated ( $0 \mathrm{kGy}$ ) and $3 \mathrm{kGy}$ e-beam irradiated samples, immediately after irradiation (T0) and after 3 (T3), 7 (T7) and 14 (T14) days of refrigerated storage. Each bar graph represents the mean and $95 \%$ confidence interval of six experiments. For each cell line, bars with * indicates a statistically significant difference from control at $p<0.05$. 
cells (Fig. 3A). Raspberries extracts, at any concentration from any treatment (non-irradiated/irradiated; non-stores/stored), had no effect ( $p>0.05$ ) on the growth of A549 lung tumor cell line (Fig. 3B), indicating that at the tested conditions the extracts had no in vitro antiproliferative activity against the tumor cells. Considering the obtained results by WST- 1 assay, the extracts at the concentrations of $4 \mu \mathrm{g} / \mathrm{mL}$ and $40 \mu \mathrm{g} / \mathrm{mL}$ from the raspberries irradiated at $3 \mathrm{kGy}$ and stored up to 7 days, had no cytotoxic effect toward the tested cells lines.

Previous studies indicated that cell lines of different origins have variable sensitivity in growth toward berry extracts (Seeram et al., 2006), as it was observed in the present study. Nevertheless, to the best of our knowledge none of the cells lines applied was studied before against raspberries extracts, but have demonstrated its applicability to evaluate antitumor activity of extracts from irradiated fruits (Madureira et al., 2019) and the cytotoxicity of plant extracts (Grauzdyte et al., 2018). In fact, raspberry extracts have shown to suppress the growth in vitro of human colon, prostate, breast, and oral tumor cells (Seeram et al., 2006; Skrovankova et al., 2015); thus other cells lines should be used to evaluate the anti-proliferative potential of extracts from e-beam treated raspberries considering the detected increases in phenolic content immediately after irradiation and in antioxidant activity after 7 days of storage.

\section{Conclusions}

E-beam irradiation was studied as a post-harvest treatment for raspberries through the evaluation of microbial inactivation and bioactivity, namely phenolic content, ascorbic acid content, antioxidant activity and cytotoxicity. The results showed that the treatment at $3 \mathrm{kGy}$ could be used to guarantee the food safety of these fruits, extending the shelf-life up to 7 days of storage. Phenolic content and antioxidant activity of raspberries seemed to be preserved with the treatment although a loss in ascorbic acid amount was detected. Moreover, no cytotoxic effect was observed for the raspberries extracts at lower concentrations irradiated at $3 \mathrm{kGy}$ and stored up to 7 days against the tested tumor and non-tumor cell lines. Further studies using different cell lines need to be performed in order to evaluate the antiproliferative activity.

\section{CRediT authorship contribution statement}

Conceptualization and Methodology: Sandra Cabo Verde; Investigation: Maria Inês Elias, Joana Madureira; Writing - Original Draft: Joana Madureira; Writing - Review \& Editing: Sandra Cabo Verde, Pedro Santos and Fernanda Margaça; Supervision: Sandra Cabo Verde and Maria Manuela Carolino.

\section{Declaration of competing interest}

The authors declare that they have no known competing financial interests or personal relationships that could have appeared to influence the work reported in this paper.

\section{Acknowledgments}

This work was developed within the Coordinated Research Project D61024 "Development of New Applications of Machine Generated Food Irradiation Technologies" financed by the International Atomic Energy Agency (IAEA). The authors are grateful to the Foundation for Science and Technology (FCT, Portugal) for financial support to C2TN (UID/ Multi/04349/2019) and J. Madureira (SFRH/BD/136506/2018).

\section{References}

Artés, F., Gómez, P., Aguayo, E., Escalona, V., \& Artés-Hernández, F. (2009). Sustainable sanitation techniques for keeping quality and safety of fresh-cut plant commodities.
Postharvest Biology and Technology, 51, 287-296. https://doi.org/10.1016/j. postharvbio.2008.10.003.

Baugher, J. L., \& Jaykus, L. A. (2016). Natural microbiota of raspberries (Rubus idaeus) and strawberries (Fragaria $\mathrm{x}$ ananassa): Microbial survey, bacterial isolation and identification, and biofilm characterization. Acta Horticulturae, 1133, 521-526. Doi:10.17660/ActaHortic.2016.1133.82.

Beekwilder, J., Hall, R. D., \& De Vos, C. H. R. (2005). Identification and dietary relevance of antioxidants from raspberry. BioFactors.. https://doi.org/10.1002/biof. 5520230404.

Benzie, I. F. F., \& Strain, J. J. (1996). The Ferric Reducing Ability of Plasma (FRAP) as a measure of "antioxidant power": The FRAP assay. Analytical Biochemistry, 239, 70-76.

Bialka, K. L., \& Demirci, A. (2007). Utilization of gaseous ozone for the decontamination of Escherichia coli O157:H7 and Salmonella on raspberries and strawberries. Journal of Food Protection, 70(5), 1093-1098. https://doi.org/10.4315/0362-028X-70.5. 1093.

Bialka, K. L., \& Demirci, A. (2008). Efficacy of pulsed UV-light for the decontamination of Escherichia coli O157:H7 and Salmonella spp. on raspberries and strawberries. Journal of Food Science. https://doi.org/10.1111/j.1750-3841.2008.00743.x.

Bobinait, R., Viškelis, P., \& Venskutonis, P. R. (2012). Variation of total phenolics, anthocyanins, ellagic acid and radical scavenging capacity in various raspberry (Rubus spp.) cultivars. Food Chemistry, 132(3), 1495-1501. https://doi.org/10.1016/j. foodchem.2011.11.137.

Bowen-Forbes, C. S., Zhang, Y., \& Nair, M. G. (2010). Anthocyanin content, antioxidant, anti-inflammatory and anticancer properties of blackberry and raspberry fruits. Journal of Food Composition and Analysis, 23(6), 554-560. https://doi.org/10.1016/j. jfca.2009.08.012.

Brand-Williams, W., Cuvelier, M. E., \& Berset, C. (1995). Use of free radical method to evaluate antioxidant activity. LWT - Food Science and Technology, 28(1), 25-30. https://doi.org/10.1016/S0023-6438(95)80008-5.

Cabo Verde, S., Trigo, M. J., Sousa, M. B., Ferreira, A., Ramos, A. C., Nunes, I., ... Botelho, M. L. (2013). Effects of gamma radiation on raspberries: Safety and quality issues. Journal of Toxicology and Environmental Health - Part A: Current Issues, 76(4-5), 291-303. https://doi.org/10.1080/15287394.2013.757256.

Callejón, R. M., Rodríguez-Naranjo, M. I., Ubeda, C., Hornedo-Ortega, R., Garcia-Parrilla, M. C., \& Troncoso, A. M. (2015). Reported foodborne outbreaks due to fresh produce in the United States and European Union: Trends and causes. Foodborne Pathogens and Disease, 12(1), 32-38. https://doi.org/10.1089/fpd.2014.1821.

Carstens, C. K., Salazar, J. K., \& Darkoh, C. (2019). Multistate Outbreaks of Foodborne Illness in the United States Associated With Fresh Produce From 2010 to 2017. Frontiers in Microbiology, 10. doi:https://doi.org/10.3389/fmicb.2019.02667.

da Câmara Correia, M. M. M. B. (2016). Caracterização química e avaliação da atividade biológica da framboesa (Rubus idaeus L.). Contribuição para o desenvolvimento de uma alegação de saúde (Faculdade de Farmácia, Universidade de Lisboa). https://doi.org/10. 22533/at.ed.8521926042.

de Souza, V. R., Pereira, P. A. P., da Silva, T. L. T., de Oliveira Lima, L. C., Pio, R., \& Queiroz, F. (2014). Determination of the bioactive compounds, antioxidant activity and chemical composition of Brazilian blackberry, red raspberry, strawberry, blueberry and sweet cherry fruits. Food Chemistry, 156, 362-368. https://doi.org/10. 1016/j.foodchem.2014.01.125.

Deutsch, J. C. (2000). Dehydroascorbic acid. Journal of Chromatography A, 881(1-2), 299-307. https://doi.org/10.1016/S0021-9673(00)00166-7.

Diaconeasa, Z., Florica, R., Rugină, D., Lucian, C., \& Socaciu, C. (2014). HPLC/PDA-ESI/ MS Identification of Phenolic Acids, Flavonol Glycosides and Antioxidant Potential in Blueberry, Blackberry, Raspberries and Cranberries. Journal of Food and Nutrition Research, 2(11), 781-785. doi:10.12691/jfnr-2-11-4.

EFSA BIOHAZ Panel - EFSA Panel on Biological Hazards. (2014). Scientific Opinion on the risk posed by pathogens in food of non-animal origin. Part 2 (Salmonella and Norovirus in berries). EFSA Journal, 12(6), 3706. doi:https://doi.org/10.2903/j.efsa. 2014.3706.

Grauzdytė, D., Pukalskas, A., Viranaicken, W., El Kalamouni, C., \& Venskutonis, P. R. (2018). Protective effects of Phyllanthus phillyreifolius extracts against hydrogen peroxide induced oxidative stress in HEK293 cells. PLoS One, 13(11), Article e0207672. https://doi.org/10.1371/journal.pone.0207672.

Guerreiro, D., Madureira, J., Silva, T., Melo, R., Santos, P. M. P., Ferreira, A., ... Cabo Verde, S. (2016). Post-harvest treatment of cherry tomatoes by gamma radiation: Microbial and physicochemical parameters evaluation. Innovative Food Science and Emerging Technologies, 36, 1-9. https://doi.org/10.1016/j.ifset.2016.05.008.

Guimarães, I. C., Menezes, E. G. T., de Abreu, P. S., Rodrigues, A. C., Borges, P. R. S. Batista, L. R., ... de Lima, L. C. O. (2013). Physicochemical and microbiological quality of raspberries (Rubus idaeus) treated with different doses of gamma irradiation. Food Science and Technology, 33(2), 316-322. https://doi.org/10.1590/ s0101-20612013005000040.

Heinonen, M. (2007). Antioxidant activity and antimicrobial effect of berry phenolics - A Finnish perspective. Molecular Nutrition \& Food Research, 51(6), 684-691. https://doi. org/10.1002/mnfr. 200700006.

Huang, Y., Sido, R., Huang, R., \& Chen, H. (2015). Application of water-assisted pulsed light treatment to decontaminate raspberries and blueberries from Salmonella. International Journal of Food Microbiology, 208, 43-50. https://doi.org/10.1016/j. ijfoodmicro.2015.05.016.

Hussain, P. R., Dar, M. A., \& Wani, A. M. (2012). Effect of edible coating and gamma irradiation on inhibition of mould growth and quality retention of strawberry during refrigerated storage. International Journal of Food Science and Technology, 47(11), 2318-2324. https://doi.org/10.1111/j.1365-2621.2012.03105.x.

Hussain, P. R., Suradkar, P., Javaid, S., Akram, H., \& Parvez, S. (2016). Influence of postharvest gamma irradiation treatment on the content of bioactive compounds and 
antioxidant activity of fenugreek (Trigonella foenum-graceum L.) and spinach (Spinacia oleracea L.) leaves. Innovative Food Science and Emerging Technologies, 33, 268-281. https://doi.org/10.1016/j.ifset.2015.11.017.

Huynh, N. K., Wilson, M. D., Eyles, A., \& Stanley, R. A. (2019). Recent advances in postharvest technologies to extend the shelf life of blueberries (Vaccinium sp.), raspberries (Rubus idaeus L.) and blackberries (Rubus sp.). Journal of Berry Research, 9(4), 709-724. https://doi.org/10.3233/JBR-190421.

Issa-Zacharia, A., Kamitani, Y., Muhimbula, H. S., \& Ndabikunze, B. K. (2010). A review of microbiological safety of fruits and vegetables and the introduction of electrolyzed water as an alternative to sodium hypochlorite solution. African Journal of Food Science, 4(13), 778-789.

Johnson, R. (2019). Foodborne Illnesses and Outbreaks from Fresh Produce. Retrieved from www.crs.gov\%7C7-5700.

Kula, M., Majdan, M., Głód, D., \& Krauze-Baranowska, M. (2016). Phenolic composition of fruits from different cultivars of red and black raspberries grown in Poland. Journal of Food Composition and Analysis, 52, 74-82. https://doi.org/10.1016/j.jfca.2016.08. 003.

Lee, H.-H., Hong, S.-I., \& Kim, D. (2014). Microbial reduction efficacy of various disinfection treatments on fresh-cut cabbage. Food Science \& Nutrition, 2(5), 585-590. https://doi.org/10.1002/fsn3.138.

Lukasik, J., Bradley, M. L., Scott, T. M., Dea, M., Koo, A., Hsu, W.-Y., ... Farrah, S. R. (2003). Reduction of poliovirus 1, bacteriophages, Salmonella Montevideo, and Escherichia coli O157:H7 on strawberries by physical and disinfectant washes $\uparrow+$ In Journal of Food Protection, 66.

Lung, H.-M., Cheng, Y.-C., Chang, Y.-H., Huang, H.-W., Yang, B. B., \& Wang, C.-Y. (2015). Microbial decontamination of food by electron beam irradiation. Trends in Food Science \& Technology, 44, 66-78. https://doi.org/10.1016/j.tifs.2015.03.005.

Madureira, J., Severino, A., Cojocaru, M., Garofalide, S., Santos, P. M. P., Carolino, M. M., ... Cabo Verde, S. (2019). E-beam treatment to guarantee the safety and quality of cherry tomatoes. Innovative Food Science and Emerging Technologies, 55, 57-65. https://doi.org/10.1016/j.ifset.2019.05.013.

McDougall, G. J., Ross, H. A., Ikeji, M., \& Stewart, D. (2008). Berry extracts exert different antiproliferative effects against cervical and colon cancer cells grown in vitro. Journal of Agricultural and Food Chemistry.. https://doi.org/10.1021/jf073469n.

Miller, A. (1983). Dosimetry for electron beam applications. Citation, 2401.

Mullen, W., Mcginn, J., Lean, M. E. J. J., Maclean, M. R., Gardner, P., Duthie, G. G., ... Crozier, A. (2002). Ellagitannins, flavonoids, and other phenolics in red raspberries and their contribution to antioxidant capacity and vasorelaxation properties. Journal of Agricultural and Food Chemistry, 50(18), 5191-5196. https://doi.org/10.1021/ jf020140n.

Oliveira, M., Rodrigues, C. M., \& Teixeira, P. (2019). Microbiological quality of raw berries and their products: A focus on foodborne pathogens. Heliyon, 5(12), https:// doi.org/10.1016/j.heliyon.2019.e02992.

Paiva De Sousa, C. (2008). The impact of food manufacturing practices on food borne diseases. Brazilian Archives of Biology and Technology, 51(4), 815-823.

Parish, M. E., Beuchat, L. R., Suslow, T. V., Harris, L. J., Garrett, E. H., Farber, J. N., \& Busta, F. F. (2003). Methods to reduce/eliminate pathogens from fresh and fresh-cut produce. Comprehensive Reviews in Food Science and Food Safety, 2, 161-173.

Pereira, E., Barros, L., Dueñas, M., Antonio, A. L., Santos-Buelga, C., \& Ferreira, I. C. F. R. (2015). Gamma irradiation improves the extractability of phenolic compounds in Ginkgo biloba L. Industrial Crops and Products, 74, 144-149. https://doi.org/10.1016/ j.indcrop.2015.04.039.

Piechowiak, T., Antos, P., Kosowski, P., Skrobacz, K., Józefczyk, R., \& Balawejder, M. (2019). Impact of ozonation process on the microbiological and antioxidant status of raspberries (Rubus ideaeus L.) during storage at room temperature. Agricultural and Food Science, 28(1), 35-44. doi:10.23986/afsci.70291.

Pimenta, A. I., Margaça, F. M. A., \& Cabo Verde, S. (2019). Virucidal activity of gamma radiation on strawberries and raspberries. International Journal of Food Microbiology, 304, 89-96. https://doi.org/10.1016/j.ijfoodmicro.2019.05.011.

Pinela, J., Barreira, J. C. M., Barros, L., Cabo Verde, S., Antonio, A. L., Carvalho, A. M., ... Ferreira, I. C. F. R. (2016). Suitability of gamma irradiation for preserving fresh-cut watercress quality during cold storage. Food Chemistry, 206, 50-58. https://doi.org/ 10.1016/j.foodchem.2016.03.050.

Puupponen-Pimia, R., Nohynek, L., Hartmann-Schmidlin, S., Kahkonen, M., Heinonen, M., Maatta-Riihinen, K., ... Oksman-Caldentey, K.-M. M. (2005). Berry phenolics selectively inhibit the growth of intestinal pathogens. Journal of Applied Microbiology, 98(4), 991-1000. https://doi.org/10.1111/j.1365-2672.2005.02547.x.

Rasiukevičiūtè, N., Valiuškaitè, A., Uselis, N., Buskienė, L., Viškelis, J., \& Lukšienè, Ž. (2015). New non-chemical postharvest technologies reducing berry contamination. Zemdirbyste-Agriculture, 102(4), 411-416. doi:10.13080/z-a.2015.102.052.

Santos, M. I., Correia, C., Cunha, M. I. C., Saraiva, M. M., \& Novais, M. R. (2005). Valores guia para avaliação da qualidade microbiológica de alimentos prontos a comer preparados em estabelecimentos de restauração. Revista Da Ordem Dos Farmacêuticos, 64, 66-68.

Sariburun, E., Sahin, S., Demir, C., Türkben, C., \& Uylaşer, V. (2010). Phenolic content and antioxidant activity of raspberry and blackberry cultivars. Journal of Food Science, 75(4), https://doi.org/10.1111/j.1750-3841.2010.01571.x.

Seeram, N. P., Adams, L. S., Zhang, Y., Lee, R., Sand, D., Scheuller, H. S., \& Heber, D. (2006). Blackberry. Black Raspberry, Blueberry, Cranberry, Red Raspberry, and Strawberry Extracts Inhibit Growth and Stimulate Apoptosis of Human Cancer Cells In Vitro.. https://doi.org/10.1021/jf061750g.

Shahbaz, H. M., Ahn, J.-J., Akram, K., Kim, H.-Y., Parl, E.-J., \& Kwon, J.-H. (2014) Chemical and sensory quality of fresh pomegranate fruits exposed to gamma radiation as quarantine treatment. Food Chemistry, 145, 312-318.

Singleton, V. L., Orthofer, R., \& Lamuela-Raventós, R. M. (1998). Analysis of total phenols and other oxidation substrates and antioxidants by means of folin-ciocalteu reagent Methods in Enzymology, 299, 152-178. https://doi.org/10.1016/S0076-6879(99) 99017-1.

Skrovankova, S., Sumczynski, D., Mlcek, J., Jurikova, T., \& Sochor, J. Bioactive compounds and antioxidant activity in different types of berries. 16 International Journal of Molecular Sciences $\S(2015)$.

Sy, K. V., McWatters, K. H., \& Beuchat, L. R. (2005). Efficacy of gaseous chlorine dioxide as a sanitizer for killing Salmonella, yeasts, and molds on blueberries, strawberries, and raspberries. Journal of Food Protection, 68(6), 1165-1175. https://doi.org/10. 4315/0362-028X-68.6.1165.

Tavoschi, L., Severi, E., Niskanen, T., Boelaert, F., Rizzi, V., Liebana, E., ... Coulombier, D. (2015). Food-borne diseases associated with frozen berries consumption: A historical perspective, European Union, 1983 to 2013. Eurosurveillance, 20(29), https://doi. org/10.2807/1560-7917.ES2015.20.29.21193.

Te Liao, Y., Syamaladevi, R. M., Zhang, H., Killinger, K., \& Sablani, S. (2017). Inactivation of listeria monocytogenes on frozen red raspberries by using uv-c light. Journal of Food Protection, 80(4), 545-550. https://doi.org/10.4315/0362-028X.JFP-16-245.

Teng, H., Fang, T., Lin, Q., Song, H., Liu, B., \& Chen, L. (2017). Red raspberry and its anthocyanins: Bioactivity beyond antioxidant capacity. Trends in Food Science and Technology, 66, 153-165. https://doi.org/10.1016/j.tifs.2017.05.015.

Tezotto-Uliana, J. V., Berno, N. D., Saji, F. R. Q., \& Kluge, R. A. (2013). Gamma radiation: An efficient technology to conserve the quality of fresh raspberries. Scientia Horticulturae, 164, 348-352. https://doi.org/10.1016/j.scienta.2013.09.026.

Wei, K., Zhou, H., Zhou, T., \& Gong, J. (2007). Comparison of aqueous ozone and chlorine as sanitizers in the food processing industry: Impact on fresh agricultural produce quality. Ozone: Science and Engineering, 29(2), 113-120. https://doi.org/10.1080/ 01919510601186592.

Wilson, J. X. (2002). The physiological role of dehydroascorbic acid. FEBS Letters. https://doi.org/10.1016/S0014-5793(02)03167-8.

Wong, P. Y. Y., \& Kitts, D. D. (2001). Factors influencing ultraviolet and electron beam irradiation-induced free radical damage of ascorbic acid. Food Chemistry, 74(1), 75-84. https://doi.org/10.1016/S0308-8146(01)00101-7.

World Healt other-ref $>$ h Organisation, \& Food and Agriculture Organization of the United Nations. (2000). FOOD IRRADIATION A technique for preserving and improving the safety of food. In Food Irradiation.

Ziegler, M., Kent, D., Stephan, R., \& Guldimann, C. (2019). Growth potential of Listeria monocytogenes in twelve different types of RTE salads: Impact of food matrix, storage temperature and storage time. International Journal of Food Microbiology, 296, 83-92. https://doi.org/10.1016/j.ijfoodmicro.2019.01.016. 